\title{
Steroid Isolated from the Dichlorometane Extract of Matoa's Stem Bark (Pometia pinnata) and Toxicity Tests Against Artemia salina Leach
}

\author{
Dian Rohmawati, Suyatno Sutoyo* \\ Departement of Chemistry, Faculty of Mathematics and Natural Sciences \\ Universitas Negeri Surabaya \\ Jl. Ketintang Surabaya, Indonesia \\ suyatno@unesa.ac.id
}

\begin{abstract}
This study is conducted to determine a steroid compound from the dichloromethane extract of matoa's stem bark (Pometia pinnata) and toxicity assay against Artemia salina Leach. In this reseacrh, extraction was carried out by maceration, separation by chromatography, purification by recrystallization, and determination of molecular structure by spectroscopic method (UV-Vis, IR, and MS). Toxicity test against shrimp larvae Artemia salina was conducted by BSLT method. The steroid isolate was obtained as colorless powder with melting point of $147-148^{\circ} \mathrm{C}$. Based on the spectroscopic data, it was identified as stigmasterol. Isolate showed toxicity against Artemia salina with $\mathrm{LC}_{50}$ of $41.334 \mu \mathrm{g} / \mathrm{mL}$.
\end{abstract} BSLT.

Keywords - Stem bark of matoa, dichloromethane extract,

\section{INTRODUCTION}

Healthy is a very important for human, because without good health everyone will be difficult in doing their daily activities. The incidence of disease is one of the causes of disruption of body health. One of the diseases that until now became a health problem in the world as well as in Indonesia is cancer.

Cancer is one of the many diseases that cause death in humans. Currently cancer is ranked second cause of death after heart disease [1]. Cancer is a disease caused by the development of abnormal cells, conditions that grow very fast, uncontrolled and not rhythmic that can infiltrate normal tissue, and ultimately suppress the development of normal tissue [2].

Cancer is an unknown disease, but there are several factors that can affect it such as active/ passive smoking, alcohol consumption, ultraviolet skin exposure, obesity and unhealthy diet, lack of physical activity, lots of instant foods, and interactions related to cancer. An unbalanced lifestyle can cause high disease growth [3].

Various efforts have been made to cope with cancer such as surgery, radiotherapy, and cytostatic chemotherapy. This treatment is done to kill cancer cells, but not a few of these efforts actually cause side effects $[4,5]$. The occurrence of hair loss and blackened skin is an effect that can result from the treatment effort [6]. This fact demands the need for a safe alternative way to the treatment of cancer by using natural ingredients.
One plant that has the potential to be developed as a bioactive compound is a plant in rambutan family (Sapindaceae). One species of Sapindaceae is the matoa (Pometia pinnata J.R \& G. Forst) belonging to the genus Pometia. It is expected that Pometia pinnata contains the same compounds as other plants in Sapindaceae family which have toxicity properties to Artemia salina as anticancer activity.

Until now there is less information or research on the chemical constituents and bioactivity of this plant. Anisa reported that $n$-hexane extract and methanol extract from matoa leave, tested its anticancer activity against Artemia salina leach nauplii with concentrations of $10 \mu \mathrm{g} / \mathrm{mL}, 50$ $\mu \mathrm{g} / \mathrm{mL}, 100 \mu \mathrm{g} / \mathrm{mL}, 500 \mu \mathrm{g} / \mathrm{mL}$, and $1000 \mu \mathrm{g} / \mathrm{mL}$. The results of toxicity test on methanol extract and $n$-hexane extract on matoa leaf showed $\mathrm{LC}_{50}$ value of $242.926 \mu \mathrm{g} / \mathrm{mL}$ and $2861.344 \mu \mathrm{g} / \mathrm{mL}$, respectively [7]. It showed that the methanol extract of matoa leaves had anticancer activity according to BLST method, because the result value obtained from LC-50<1000 $\mu \mathrm{g} / \mathrm{mL}$. From the results of phytochemical schemes it was known that the methanol extract of matoa leaves contained flavonoid, saponins, steroids, triterpenoids, polyphenols, and tannins.

Matoa is one of Indonesia's biological riches that had been used as a traditional medicine in the treatment of wounds, fever, diarrhea, cough, diabetes and others [8].

In an attempt to prove the claim of the use of matoa plants in traditional medicine, it is necessary to research the chemical content in the plant. Biological activities such as antiseptic properties (antimicrobial activity), antioxidant power or toxicity of the plant are supported by the presence of chemical compounds is secondary metabolite compounds contained in them such as triterpenoid group compounds, steroids, flavonoids, alkaloids and phenolic compounds. The more active secondary metabolite compounds are conceived, the stronger the plant is used in the treatment [9]. Therefore, research on the isolation of non-phenolic compounds from the dichloromethane extract of matoa's stem bark (Pometia pinnata J.R \& G. Forst) and toxicity test against Artemia salina Leach as anticancer preliminary test for its utilization as alternative treatment to be maximal. 


\section{MATERIALS AND METHODS}

\section{A. Materials}

Materials used in the study were stem bark of matoa, $n$ hexane, dichloromethane, ethyl acetate, chloroform, methanol, spray reagents, kieselgel G 60 F-254 (Merck), silica gel G 60 63-200 $\mu \mathrm{m}$ (Merck), precoated silica gel G 60 F-254 (Merck) plate $(20 \times 20 ; 0,25 \mathrm{~mm})$, DMSO, seawater and Artemia salina.

\section{B. Instruments}

The instruments used in this research were a set of extraction tools, a set of Buchner filter, vacuum pump (Dreh Schieber Vacum Pumpe DSEZ), vacum rotary evaporator (Buchi), Fisher John melting point apparatus, UV spectrophotometer (Shimadzu Pharma Spec. UV-1700), FTIR (Perkin Elmer USA 89485), Mass spectrophotometer (Shimadzu QP-2010S ), a set of sprayer, and glassware.

\section{Sample Preparation}

The stem bark of matoa was obtained from Sakartemin village, Fak-Fak, West Papua, Indonesia. Before the research it was identified by the Indonesian Institute of Sciences of the Purwodadi Botanical Garden, East Java, Indonesia. Furthermore the sample of the stem bark of matoa was cleaned, dried at room temperature, and then milled into a fine powder ready to be extracted.

\section{Extraction and Isolation}

The dried powder of matoa's stem bark $(3 \mathrm{~kg})$ were extracted by maceration method successively using $n$ hexane and dichloromethane for $3 \times 24$ hours with 5 liter of solvent for each maceration. The dichloromethane extract on removal of the solvent using the rotary evaporator resulte the blackish green solid $(9.3 \mathrm{~g})$. A portion of dichloromethane extract $(5 \mathrm{~g})$ was separated by vacuum liquid chromatography (VLC) using using kieselgel G 60 F254 (Merck) as stationary phase eluted consecutively with $n$-hexane, $n$-hexane-ethyl acetate mixture, and ethyl acetate, yielded 114 fractions. The result of the separation was monitored by thin layer chromatography (TLC) using precoated silica gel G 60 F-254 (Merck) eluted by the mixture of n-hexane-ethyl acetate $(4: 1)$. The combined fractions of 51-54 were recrystallized in methanol gave isolate $(293 \mathrm{mg})$.

\section{E. Preliminary Test of Anticancer Activity}

Isolate $(5 \mathrm{mg})$ was dissolved in chloroform $(1 \mathrm{~mL})$. The resulted solution was called the mother liquor with a concentration of $5000 \mu \mathrm{g} / \mathrm{mL}$. The mother liquor was then pipeted as much as $10,25,50,75$, and $100 \mu \mathrm{L}$ and inserted each into different vials. Furthermore each vial is allowed until the solvent evaporates, then added DMSO and inserted 10 Artemia salina larvae. Further filled with sea water until volume $5 \mathrm{~mL}$ and left for 48 hours. The number of dead shrimp larvae was counted. The results obtained were analyzed by probit analysis using SPSS program to determine the $\mathrm{LC}_{50}$ value [10].

\section{RESULTS AND DISCUSSION}

A. Isolation of Secondary Metabolite from the Dicholoromethane Extract of Matoa's Stem Bark

The separation of secondary metabolites from dichloromethane extract of matoa's stem bark was conducted by vacuum liquid chromatography (VLC) followed by purification using recrystallization. From this process it was obtained a isolate in the form colorless powder with melting point of $147-148^{\circ} \mathrm{C}$.

Isolate showed one spot in TLC using three eluent systems, namely $\mathrm{Rf}=0.59$ ( $n$-hexane-ethyl acetate $=4: 1)$, $\mathrm{Rf}=0.14(n$-hexane-ethyl acetate $=9: 1)$, and $\mathrm{Rf}=0.82(n-$ hexane-chloroform $=1: 1)$. It also showed positive results (greenish blue) on the qualitative test using Liebermann Burchard reagent so it was steroid compound. The ultraviolet spectrum of isolate showed the maximum absorption peak at a wavelength of $202 \mathrm{~nm}$. It indicated the electron transition $\pi \rightarrow \pi^{*}$ of the unconjugated double bond $\mathrm{C}=\mathrm{C}$ in the result of the insulating compound. The IR spectrum prepared by $\mathrm{KBr}$ pellet technique gave absorption bands of $\mathrm{OH}\left(3425.69 \mathrm{~cm}^{-1}\right)$, alkyl C-H (2935.76 and $\left.2850.88 \mathrm{~cm}^{-1}\right), \mathrm{C}=\mathrm{C}\left(1633.76 \mathrm{~cm}^{-1}\right)$, and $\mathrm{C}-\mathrm{O}(1168.90$ and $\left.1049.31 \mathrm{~cm}^{-1}\right)$. The presence of that functional groups supported that isolate was steroid. The mass spectrum of isolate had a relative molecular mass of 412 which gave peaks of fragment ions at $\mathrm{m} / \mathrm{z} 412,379,369,351,314,300$, $285,271,255,239,227,213,199,185,173,159,145,133$, $119,105,91,81,69,55,41$, and 29 . The relative molecular mass of 412 corresponding to the $\mathrm{C}_{29} \mathrm{H}_{48} \mathrm{O}$ molecular formula. The fragmentation pattern shown in the mass spectrum supports that the isolate was a stigmasterol compound . Based on spectroscopic data (UV, IR, and MS) above and the comparison of the literature it can be concluded that the resulting isolate is a stigmasterol compound which can be described as follows:

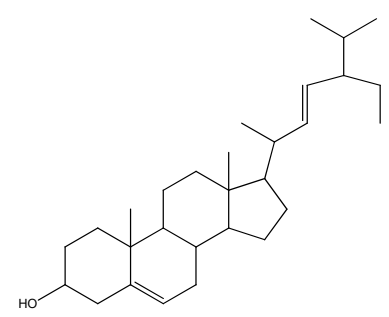

Fig 1. Stigmasterol (Susidarti, 2007)

The discovery of the stigmasterol from matoa's stem bark is the first time from this plant and plant in Pometia genus. However, the stigmasterol compound has been reported from the root crop M. umbellata (Houtt) Stapf var. degrabrata $\mathrm{K}$. who successfully isolated the stigmasterol (5,22-stigmastadien-3 $\beta$-ol) [11].

\section{B. Toxicity Test of Isolate against Artemia salina Leach}

Based on toxicity to Artemia salina as anticancer preliminary test using Brine Shrimp Lethality Test (BSLT) 
method showed that positive isolates have potency as anticancer. The result of probit analysis using SPSS obtained $\mathrm{LC}_{50}$ value of $41.334 \mu \mathrm{g} / \mathrm{mL}$.

Based on the $\mathrm{LC}_{50}$ value, the toxicity of the isolates can be categorized as highly toxic because the $\mathrm{LC}_{50}$ values are between $0-250 \mu \mathrm{g} / \mathrm{mL}$ [10]. Based on the $\mathrm{LC}_{50}$ values of the isolates that are categorized as highly toxic according to the toxicity classification, it can be said that the isolates from the dichloromethane extract of the matoa's stem bark had potential as anticancer agent.

In a BSLT test of media in which Artemia salina Leach's life was given a stigmatized steroid compound isolated solution. These compounds enter the body of Artemia salina Leach. shrimp larvae that interfere with the gastrointestinal tract that can cause the death of Artemia salina Leach because Artemia salina Leach has a filtering properties of non-selective filters so that anything that enters the mouth of Artemia salina Leach is considered as food.

Gabay stated that stigmasterol was useful in the prevention of certain cancers, including ovaries, prostate, breast, and colon cancer [12]. Several steroid compounds contained in isolates from red bromide stem dichloromethane extract (Rhizopora stylosa) are highly toxic for Artemia salina L. shrimp larvae with LC-50 values of $65.432 \mu \mathrm{g} / \mathrm{mL}$ [13]. Based on Ririn's research (2016), the result of non-phenolic compound (steroid) from ashitaba stem dichloromethane extract (Angelica keiskei) has potential as anticancer in preliminary test with BSLT method obtained LC-50 value of $119.048 \mu \mathrm{g} / \mathrm{mL}$ and has very high toxicity rate of toxicity to mortality rates of shrimp larvae Artemia salina Leach [14].

\section{CONCLUSIONS}

Based on the results of the research and discussion that has been presented, it can be concluded that the isolates from the extract dichloromethane of matoa's stem bark (Pometia pinnata) is steroid compound, namely stigmasterol. It showed very toxic activity in BSLT test using Artemia salina larvae with $\mathrm{LC}_{50}$ value of 41.334 $\mu \mathrm{g} / \mathrm{mL}$. Thus the isolate had potential as an anticancer agent.

\section{ACKNOWLEDGMENT}

We thank Mr. Trimanto, M.Si. from the Indonesian Institute of Sciences (LIPI) UPT for the Plant Conservation Center of Purwodadi Botanical Garden, Pasuruan, East Java, Indonesia for identifying the plant material.

\section{REFERENCES}

[1] A, Ghofar, Cara Mudah Mengenal dan Mengobati Kanker. Yogyakarta: Flamingo, 2009.

[2] R, Diananda, Mengenal Seluk-Beluk Kanker. Jogjakarta: Katahati, 2008.

[3] M, Ikawati, Eko W. A., Sri O. N., dan Rosa A, "Utilization of parasites as an anticancer agent (Pemanfaatan benalu sebagai agen antikanker)", Jurnal Farmasi, Universitas Gadjah Mada, 1(1) pp: 1$8,2000$.

[4] Sukardiman, Abdul, R., dan Fatma P.N, "Pre-screening test of anticancer activity of ether extract and methanol extract of Steph Marchantia planiloba with shrimp larvae mortality test method and active extract densitometry profile (Uji praskrining aktivitas antikanker ekstrak eter dan ekstrak metanol Marchantia planiloba Steph. dengan metode uji kematian larva udang dan profil densitometri ekstrak aktif)", Jurnal Farmasi Airlangga, 4 (3) pp: 97$100,2004$.

[5] S, Moeljopawiro., M. R. Anggelia. D, Ayuningtyas. B, Widaryanti. Y, Sari, dan I. M, Budi, "Effect of red fruit juice (Pandanus conoideus Lam) on the growth of breast cancer cells and colon cancer cells (Pengaruh sari buah merah (Pandanus conoideus Lam) terhadap pertumbuhan sel kanker payudara dan sel kanker usus besar)". Berkala Ilmiah Biologi. 6(2) pp: 121-130, 2007.

[6] Q, Jiang., J. Wong, H. Fryst, J.D, Saba, dan B.N. Ames, “ $\gamma-$ Tocopherol or combination of vitamin $\mathrm{E}$ form induce cell death in human prostate cancer cell by interrupting sphingolipid synthesis", PNAS. 101 (51) pp: 17825-17830, 2004.

[7] Anisa Dyah, S.M, "Praskrinning test anticancer activity of matoa leaves (Pometia pinnata) with brine shrimp lethality test method ( $n$ hexane extract and methanol extract) (Uji praskrinning aktivitas antikanker daun matoa (pometia pinnata) dengan metode brine shrimp lethality test (ekstrak n-heksana dan ekstrak metanol), Malang", Program Studi Farmasi, Fakultas Ilmu Kesehatan, Universitas Muhammadiyah Malang, 2012.

[8] Thomson, L.A.J. dan R.R.Thaman, "Pometia pinnata (Tava), spesies profiles for pacific island agroforestry, permanent agriculture resources", 11, 2006

[9] M, Sirait, Pengembangan Obat Bahan Alam: Bahan Seminar Perhimpunan Peneliti Obat Bahan Alam. Jakarta: ISTN, 2001.

[10] B.N Meyer., Ferrigni, N.R, Putnam, J.E, Jacobsen, L.B, Nichols, D.E, dan McLaughlin, J.L, "Brine shrimp: a convenient general bioassay for active plant constituents", Planta Medica, 45, pp: 31-34, 1982.

[11] A, Ridhay., Noor, A., Soekamto, N.H., dan Halim, T,. "Isolation and antibacterial test of steroid compounds from wood roots of $\mathrm{M}$. umbellata (Houtt) Stapf var. degrabrata K (Isolasi dan uji antibakteri senyawa steroid dari kayu akar M. umbellata (Houtt) Stapf var. degrabrata K)", Jurnal Kesehatan Bung. 1 (4) :pp: 43-46, 2012.

[12] M, Gabay., Tanzi, M, Guideline for The Management of Febrile Neutropenia. Educational Review, University of Llionis at Chaniago College of Pharmacy Chicago. Lllionis, pp. 1-5, 2009.

[13] R.R, Mukharromah, \& Suyatno, "Secondary metabolite compound from dichloromethane extract of red mangrove stem skin (Rhizophora Stylosa) (Senyawa metabolit sekunder dari ekstrak diklorometana kulit batang bakau merah (Rhizophora Stylosa))", UNESA Journal of Chemistry. 3 (3) pp: 154-158, 2014.

[14] S.R, Hartini., dan Suyatno, "Identification and preliminary test of anticancer activity of non-phenolic compounds from dichloromethane extract of plant stem ashitaba (Angelica keiskei) (Identifikasi dan uji pendahuluan aktivitas antikanker senyawa non fenolik dari ekstrak diklorometana batang tumbuhan ashitaba (Angelica keiskei))", UNESA Prosiding Seminar Nasional Kimia dan Pembelajarannya, ISBN: 978-602-0951-12-6, 2016. 